ECCOMAS

\section{Proceedia}

COMPDYN 2021

$8^{\text {th }}$ ECCOMAS Thematic Conference on Computational Methods in Structural Dynamics and Earthquake Engineering

M. Papadrakakis, M. Fragiadakis (eds.) Streamed from Athens, Greece, 28 - 30 June 2021

\title{
EXPERIMENTAL IN-PLANE LATERAL RESPONSE OF A FULL-SCALE ADOBE MASONRY WALL WITH OPENING
}

\author{
Paolino Cassese $^{1}$, Luigi Fenu ${ }^{2}$, Domenico Asprone ${ }^{3}$ Antonio Occhiuzzi $^{4,5}$ and \\ Fulvio Parisi ${ }^{3}$ \\ ${ }^{1}$ National Research Council (CNR), Construction Technologies Institute (ITC) \\ c/o Polo Tecnologico di San Giovanni a Teduccio, Naples, Italy - paolino.cassese@itc.cnr.it \\ ${ }^{2}$ University of Cagliari, Department of Civil Engineering, Environment Engineering and Architecture \\ Via Marengo 2, Cagliari, Italy - 1fenu@unica.it \\ ${ }^{3}$ University of Naples Federico II, Department of Structures for Engineering and Architecture \\ Via Claudio 21, Naples, Italy - d.asprone@unina.it, fulvio.parisi@unina.it \\ ${ }^{4}$ National Research Council (CNR), Construction Technologies Institute (ITC) \\ Viale Lombardia, 49, San Giuliano Milanese, Italy - occhiuzzi@itc.cnr.it \\ ${ }^{5}$ University Parthenope, Department of Engineering \\ Centro Direzionale Isola C4, 80143 Naples, Italy - antonio.occhiuzzi@uniparthenope.it
}

\begin{abstract}
A large amount of world population lives nowadays in earthen buildings, often constructed only based on construction practice and within earthquake-prone regions. In the recent histo$r y$, several strong earthquakes had dramatic consequences on these structures, highlighting their significant seismic vulnerability due to multiple reasons, such as poor mechanical properties, poor detailing, and large inertia mass. Several aspects of seismic performance of existing earthen constructions need to be investigated through full-scale experimental testing. In this regard, the present study aims at contributing to the investigation by testing a full-scale adobe masonry wall with a central door-type opening under in-plane lateral loading with cyclic fashion. The mechanical behaviour of materials, specimen's design, loading protocol and instrumentation setup are described. The experimental response curves, observed damage evolution and failure mode are discussed, especially focusing on dissipation capacity of the wall.
\end{abstract}

Keywords: Full-scale tests; Adobe masonry; Walls; Cyclic tests; Seismic capacity. 


\section{INTRODUCTION}

Unreinforced masonry (URM) structures represented the most popular solution for buildings adopted in many countries up to the last century, when other construction technologies became progressively more common [1]. Thus, a large portion of the existing building stock around the world is made of URM structures, often within high-seismicity regions such as Europe and Pacific Rim countries [2]. Among URM typologies, adobe masonry (AM) represents one of the most ancient and widespread for historical construction as well as currently still used for construction of low-cost dwellings in less developed areas of the world [3-4]. Recently, several reconnaissance missions after strong earthquakes [5-9] revealed the considerable vulnerability of existing URM structures, with severe damages and frequent global collapses resulting in significant losses.

This framework led researchers in increasing interest on the seismic assessment and retrofitting of URM members during last few decades, resulting in numerous experimental investigations. Firstly, these studies were mainly focused on the mechanical behaviour of URM walls representative of masonry piers, on the basis that these latter governed seismic response of the structure, whereas spandrel panels were considered secondary elements [10-11, among many others]. Then, several studies established the key role of spandrel panels in loadcarrying capacity under lateral actions [12-13], thus several testing programs were performed on both reduced-scale full-buildings and spandrels. Benedetti et al. [14] presented the experimental results of 24 shaking-table tests on 1:2 scaled models of two-story masonry buildings before and after cracks-repairing and strengthening of spandrels. The as-built specimens were characterized by severe cracks localized on spandrel-panels and showed higher capacity than strengthened ones for which critical damage occurred in the piers resulting in premature collapse. A full-scale prototype of two-story URM building was tested under increasing cyclic lateral load in both as-built and strengthened conditions by Moon and his co-authors [2, 15]. A combined strengthening system was applied to the structure, made of fibre reinforced plastic e post-tensioning devices, proving to be considerably effective in improving original seismic capacity. Bothara et al. [1] performed a shaking-table test on a half-scale model of an existing New Zeland URM structure with two stories, gable walls, inclined roof and slightly eccentricity. The unreinforced test-building was prior shacked along longitudinal direction, then repaired and tested in the opposite direction. Intense rocking and out-of-plane phenomena were observed, especially on gable walls and experimentally-based fragility curves were derived. The results of an experimental campaign on URM spandrels ware presented in [1618]. Specific testing setups were realized in order to reproduce piers constraint effects and properly apply the cyclic lateral loading. Different spandrel configurations were tested showing that their strength and failure modes were governed by the axial load acting along the member. Chourasia et al. [19] carried out quasi-static cyclic tests on full-scale single-room URM building composed of four orthogonal walls connected to a reinforced concrete (RC) slab on top, before and after strengthening by means of RC bands. Typical Indian materials were adopted for masonry. Brittle failure was observed for the unreinforced specimen, with huge diagonal cracks and sliding of RC roof, whereas the repaired one showed substantial strength improvement.

A first example of in-plane cyclic testing on full-sized URM wall with door-opening representative of a structural sub-assemblage was reported in [20]. Firstly, monotonically increasing lateral load was applied until damage occurred in the spandrel. Then, this latter was strengthened by means of inorganic reinforced matrix and further cyclic tests were carried out on the wall. Experimental evidence showed that most of the observed damage was localized in the spandrel-panel, whereas rocking of piers governed the hysteretic response, and the 
strengthening system was effective in improving lateral response. Knox and his co-authors presented two experimental studies [21-22] focusing on the influence of spandrel panels on the mechanical response of URM structures under in-plane cyclic lateral loads. Pier-spandrel sub-assemblages were tested in [21] in which different failure modes of the whole structure were observed depending on different spandrel's aspect-ratio (namely, height-to-width ratio). The experimental outcomes derived from testing a half-scale two-story perforated (i.e., with multiple door- and window-type openings) URM wall were provided in [22]. The shallow spandrels behaved as coupling beams for masonry piers which were governed by rocking mechanism resulting in an elastic-perfectly plastic response with notable displacement ductility. More recently, an experimental and numerical study was carried out by Choudhury et al. [23] on typical Indian URM buildings. Specifically, the Authors performed cyclic in-plane tests on three different full-scale walls (respectively, with a door in the middle, a window in the centre and a solid wall) and a single-story one-room building, observing combined flexural action and sliding shear. Finally, Howlader et al. [24] experimentally investigated in-plane cyclic response of eight full-scale URM walls with semi-circular arched openings and materials typical of Australian last-century constructions. Specimens were different in terms of dimensions of spandrels and piers as well as imposed vertical loads. The observed lateral load capacity and failure modes were governed by changes in wall geometry.

The experimental study presented in this paper fits in this line of research focusing on the mechanical response of a perforated adobe masonry wall, with a central door-type opening, under quasi-static in-plane cyclic loading. Notice that, currently, no similar experimental studies are available in literature. A proper experimental characterization carried out for the adopted materials, i.e. adobe bricks and mud mortar representative of existing Italian earthen buildings and largely widespread in Sardinia island [25-26], is described according to a multiscale approach. Then, geometry of the wall specimen and details of the experimental program are illustrated. Then, test results are presented and discussed in terms of both observed damage and response curves.

\section{EXPERIMENTAL PROGRAM}

A full-scale AM wall with a central door-type opening was constructed within the structural laboratory at the University of Naples Federico II. The wall specimen was tested into place under cyclically increasing lateral displacements and constant vertical loading. In the following, a detailed description of material properties is reported according to a multiscale approach, from constituents to the behaviour of the adobe masonry under uniaxial compression and shear. Then, the geometry of the wall specimen, test set-up and monitoring instrumentation along with loading protocol are described.

\subsection{Material properties}

The wall specimen was made of adobe bricks and mud mortar. Bricks were obtained by reproducing the non-industrial manufacturing process, mainly based on the worker's experience, in compliance with Sardinian construction practice. Local soil, classified as clayey-silty sand, was mixed with water and straw fibres by volume. Specifically, randomly oriented straw fibres with different dimensions were added to a first soil/water mixture. Subsequently, some water or soil was added based on the mixture appearance evaluated by the manufacturer. Then, the final form was achieved by filling a prismatic wood formwork characterized by internal grooved surface and the wet brick was left to dry to the sun. On average, straw fibres had diameter equal to $3 \mathrm{~mm}, 70 \mathrm{~mm}$ length and $0.64 \%$ percentage by weight. Density and water content were $2.68 \mathrm{~g} / \mathrm{cm}^{3}$ and $27 \%$, respectively. Each adobe bricks was $200 \times 400 \times 100 \mathrm{~mm}^{3}$ in 
size. The resulting mean unit weight was equal to $16.80 \mathrm{kN} / \mathrm{m}^{3}$ with a very limited coefficient of variation $(\mathrm{CoV}=2 \%)$. Mud mortar used for masonry joints had same particle size of earth bricks, but no fibres were added to the mixture as typical of Sardinian adobe masonry [25, 27]. Nevertheless, a different amount of water was added during the mixing operations until a $20 \%$ optimal water content by volume was reached, in tune with trend from literature [28]. More detailed description of the production process and physical properties can be found in [26].

Mechanical properties of both adobe bricks and mud mortar were derived through uniaxial compression and three-point bending tests. Overall, compressive standard tests [29] were performed on 6 and 36 cubic specimens, respectively for mortar and bricks, from which mean values of compressive strength $\left(f_{c}\right)$ equal to $0.50 \mathrm{MPa}(\mathrm{CoV}=14 \%)$ and $1.08 \mathrm{MPa}(\mathrm{CoV}=$ $36 \%$ ) were derived. Standard three-point bending tests on specimens $40 \times 40 \times 160 \mathrm{~mm}^{3}$, in compliance with the European standard EN 1015-11 [30], were carried out for assessing tensile properties. In this case, for the adobe bricks test-specimens were extracted from original units, whereas for mortar characterization they were moulded into standard formwork. A total of 8 tests were performed on mud mortar and 36 on adobe bricks. Notice that higher number of experimental tests were systematically conducted for bricks in order to properly taking into account the further source of variability in mechanical response due to straw fibres with respect to mud mortar. On average, tensile strength $\left(f_{t}\right)$ of adobe bricks was $0.56 \mathrm{MPa}(\mathrm{CoV}=$ $36 \%)$ whereas a lower value $\left(f_{t}=0.45\right)$ was obtained for mud mortar, as expected due to absence of fibres reinforcement, with $\mathrm{CoV}$ equal to $20 \%$. Typical observed failure modes of tested specimens in tension and compression are shown in Figure 1. Furthermore, main materials mechanical properties are summarized in Table 1.

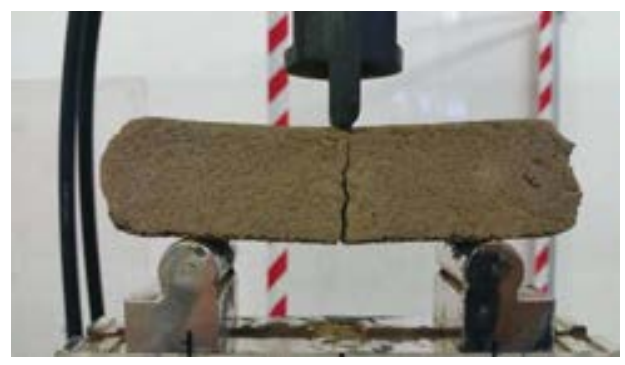

(a)

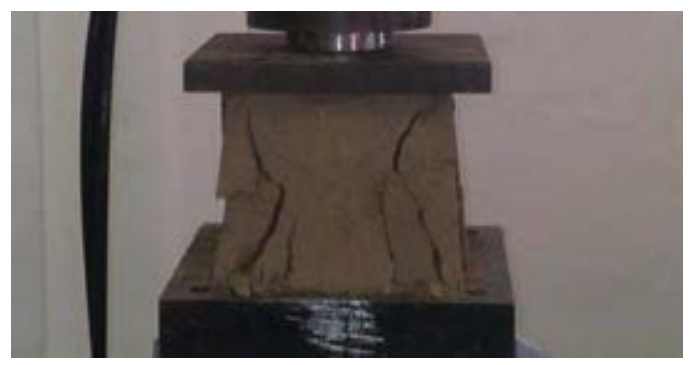

(b)

Figure 1: Typical failure modes of material test specimens in tension (a) and compression (b).

\begin{tabular}{|c|c|c|c|c|}
\hline Material & $\begin{array}{l}f_{c} \\
{[\mathrm{MPa}]}\end{array}$ & $\begin{array}{l}f_{t} \\
{[\mathrm{MPa}]}\end{array}$ & $\begin{array}{l}E_{c} \\
{[\mathrm{MPa}]}\end{array}$ & $\begin{array}{l}E_{t} \\
{[\mathrm{MPa}]}\end{array}$ \\
\hline Bricks & $\begin{array}{l}1.08 \\
(36 \%)\end{array}$ & $\begin{array}{l}0.56 \\
(36 \%)\end{array}$ & $\begin{array}{l}143 \\
(40 \%)\end{array}$ & $\begin{array}{l}69 \\
(29 \%)\end{array}$ \\
\hline Mortar & $\begin{array}{l}0.50 \\
(14 \%)\end{array}$ & $\begin{array}{l}0.45 \\
(20 \%)\end{array}$ & $\begin{array}{l}47.5 \\
(35 \%)\end{array}$ & $\begin{array}{l}20.5 \\
(33 \%)\end{array}$ \\
\hline
\end{tabular}

* Coefficient of variation reported in round brackets.

Table 1: Main mechanical properties of AM constituents*. 


\subsection{Experimental characterization of adobe masonry under uniaxial compression and shear}

In addition to base materials, associated to bricks and mortar, the mechanical behaviour of the adobe masonry used for construction of the wall specimen was furtherly investigated by testing at the level of the elementary sub-assemblage. Specifically, mechanical properties of adobe masonry wallets under compression and shear, respectively, were assessed by means of uniaxial compression and diagonal compression tests.

Uniaxial compression tests were carried out on 8 adobe masonry single-leaf running-bond wallets with size $610 \times 650 \times 200 \mathrm{~mm}^{3}$, composed of six horizontal courses and 10 -mm-thick mud mortar joints. Wallets were subjected to monotonically increasing vertical displacement by means of a universal electro-hydraulic testing machine with a $2000 \mathrm{kN}$ force capacity and total stroke of $\pm 150 \mathrm{~mm}$. In order to achieve uniform distribution of axial stress a rigid steel beam was interposed between machine loading head and top of masonry prism. A load cell was used to measure applied force acting on specimen, whereas the deformations were measured by means of a specific monitoring-system composed of linear variable displacement transducers (LVDTs) installed vertically in the middle of the panel and horizontally along specimen's thickness to monitor splitting phenomena at failure. Normal stress $(\sigma)$ was derived considering the gross cross-section of the wallet whereas vertical strain $(\varepsilon)$ was computed from records of vertical LVDTs.

For all specimens, failure mode was characterized by cracks along compressive isostatic lines, involving both bricks and joints (see Figure 2a,b), and considerable splitting observed within specimen thickness. Resulting stress-strain $(\sigma-\varepsilon)$ curves are reported in Figure 2c. Compressive strength of the adobe masonry $\left(f_{c, a m}\right)$ was equal to $1.32 \mathrm{MPa}$, on average, slightly higher than bricks, with low dispersion $(\mathrm{CoV}=8 \%)$. Conversely, larger scatter was recorded for Young's modulus $\left(E_{c, m}\right)$, evaluated at half peak-stress, the mean value of which was 425.4 MPa with $\mathrm{CoV}=25 \%$.

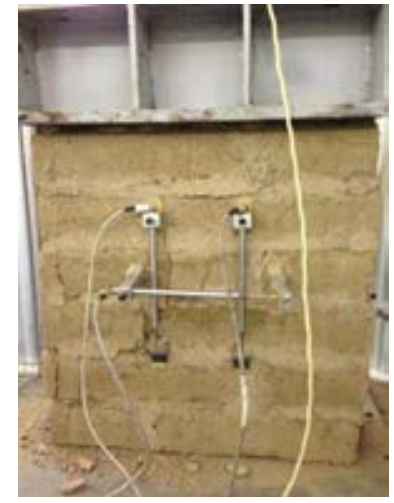

(a)

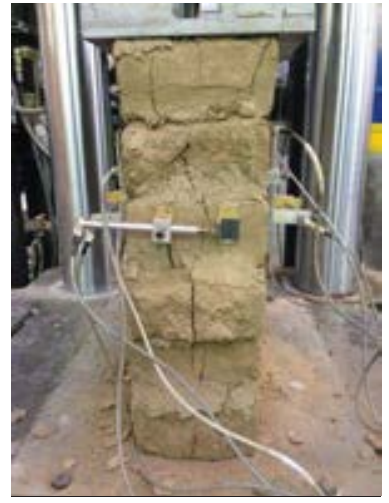

(b)

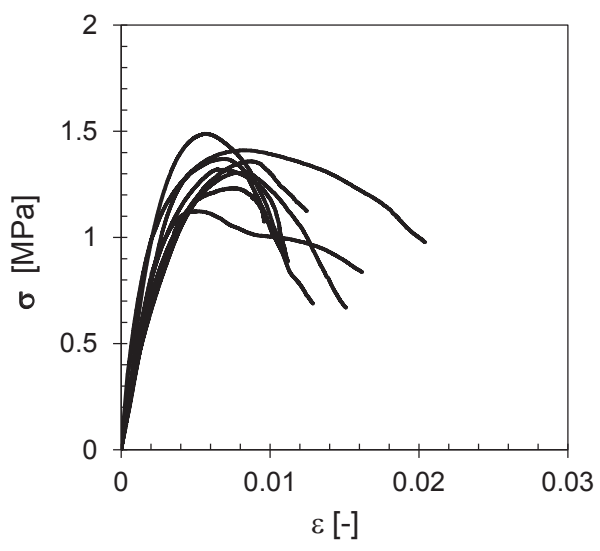

(c)

Figure 2: Typical damage state corresponding to compression failure (a,b) and stress-strain response curves (c).

Shear response of AM masonry was assessed by means of diagonal compression tests on seven wallets of total size of $410 \times 1230 \times 1230 \mathrm{~mm}^{3}$ and running bond configuration Such specimens were built on specific supports in order to allow for the execution of testing by means of the portable loading set-up depicted in Figure 3a. This latter was composed of a steel closed reaction-system acting as contrast to ejection of the hydraulic-jack interposed on the specimen. The adopted testing set-up was able to reduce either disturbance of wallets due 
to transportation to laboratory and preparation time. The testing machine reached maximum load of $500 \mathrm{kN}$ and total stroke equal to $\pm 75 \mathrm{~mm}$. Double pair of linear variable differential transformers (LVDTs), with $400 \mathrm{~mm}$ gauge length, were installed in the middle of masonry external panels to monitoring the deformations along specimen's diagonal. Experimental records were processed according to the American standard ASTM E519-15 [31] in order to derive shear stress and strain $(\tau-\gamma)$. Typical final damage state is reported in Figure $3 \mathrm{~b}$. Diagonaltension failure mode occurred with cracking patterns characterized by wide passing-through diagonal cracks generally involving both joints and bricks. Response $\tau-\gamma$ curves of all tested wallets are shown in Figure 3c. AM specimens were characterised by a pseudo-elastic branch up to peak shear stress followed by limited softening until collapse occurred. Post-peak softening response was considerably different among specimens. Peak shear stress $\left(\tau_{\max , m}\right)$ equal to $0.107 \mathrm{MPa}$ was obtained on average, with limited dispersion $(\mathrm{CoV}=7 \%)$, whereas the mean value of the initial shear modulus $\left(G_{i}\right)$, assumed as secant at $\tau_{\max } / 4$, was equal to 185 $\mathrm{MPa}(\mathrm{CoV}=33 \%)$.

Table 2 summarizes strength and stiffness mean properties obtained for elementary AM sub-assemblage under axial compression and shear along with their $\mathrm{CoV}$.

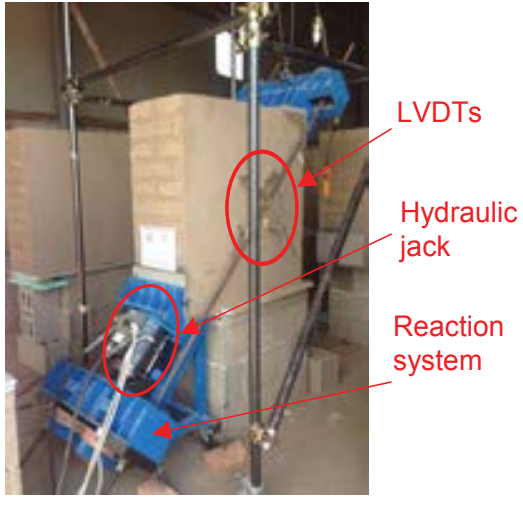

(a)

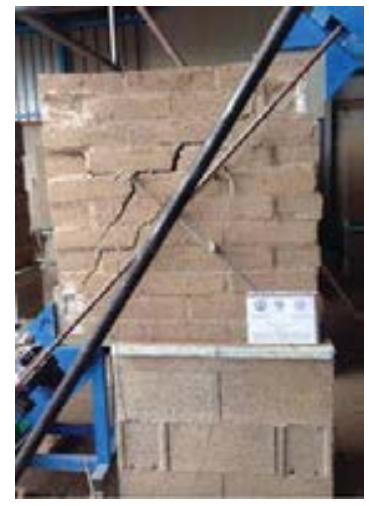

(b)

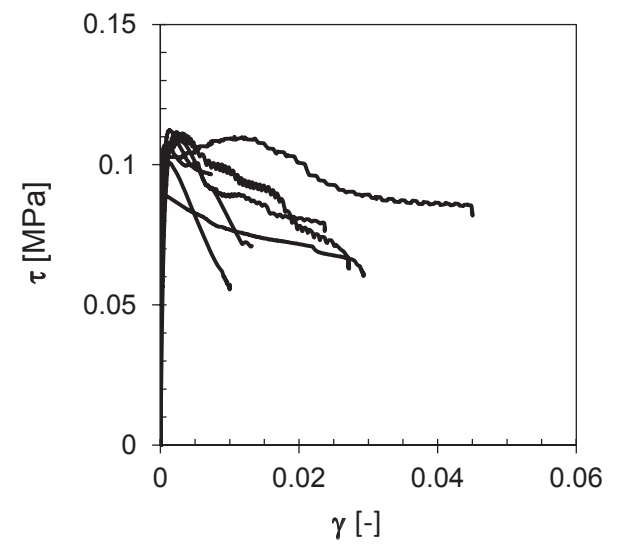

(c)

Figure 3: Diagonal compression tests on AM wallets: test set-up (a), typical failure mode (b), $\tau-\gamma$ curves (c).

\begin{tabular}{|c|c|c|c|c|}
\hline \multirow[t]{3}{*}{ Statistic } & \multicolumn{2}{|c|}{ Compressive properties } & \multicolumn{2}{|c|}{ Shear properties } \\
\hline & $f_{c, m}$ & $E_{c, m}$ & $\tau_{\max , m}$ & $G_{i}$ \\
\hline & {$[\mathrm{MPa}]$} & {$[\mathrm{MPa}]$} & {$[\mathrm{MPa}]$} & {$[\mathrm{MPa}]$} \\
\hline Mean & 1.32 & 425.4 & 0.107 & 185 \\
\hline $\mathrm{CoV}$ & $(8 \%)$ & $(25 \%)$ & $(7 \%)$ & $(33 \%)$ \\
\hline
\end{tabular}

* Coefficient of variation reported in round brackets.

Table 2: Mean values of mechanical properties of adobe masonry*.

\subsection{Geometry of the specimen}

The AM specimens was a full-scale single-leaf masonry wall with a door-type opening in the middle-length (Figure 4). The latter was $1.70 \mathrm{~m}$-long and $2.00 \mathrm{~m}$-high. The two adjacent masonry piers had same opening's dimensions and were interconnected by a spandrel panel with height of $1.00 \mathrm{~m}$. Three masonry layers were built above the piers in order to ensure proper vertical-load distribution. At the spandrel-panel intrados a wooden lintel was installed 
with $150 \mathrm{~mm}$ anchorage-length within the piers. Therefore, the wall had total height and length equal to $3.60 \mathrm{~m}$ and $5.10 \mathrm{~m}$, respectively, and $400 \mathrm{~mm}$ thickness.

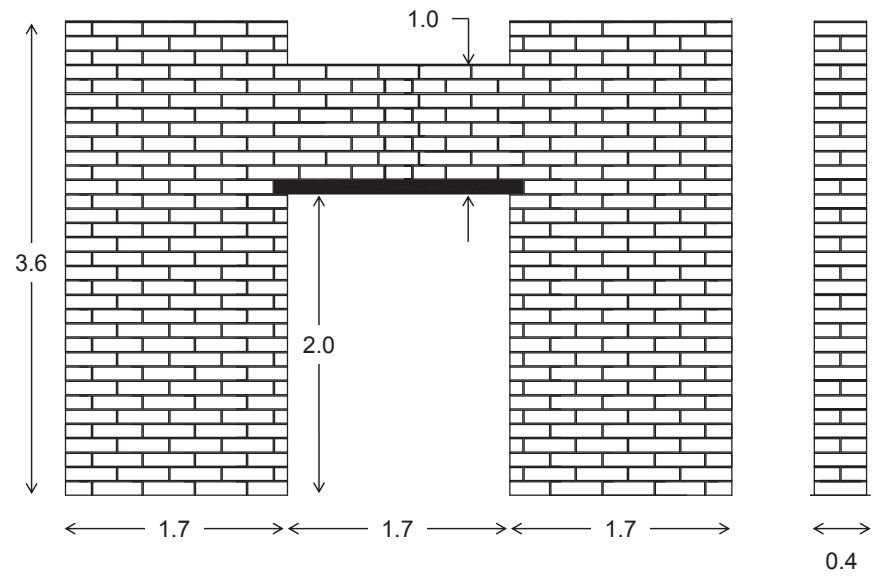

Figure 4: Frontal and lateral views of the adobe wall specimen (dimensions in $\mathrm{m}$ ).

\subsection{Test set-up and instrumentation}

The specimen was erected on a rigid reinforced concrete (RC) beam, acting as wallfoundation. Such basement was anchored to the strong floor of the testing laboratory by means of pre-tensioned high-strength steel rebars. Vertical load on piers, kept constant during the test, was applied by means of two hydraulic jacks (one for each pier). Each hydraulic jack pushed against a steel reaction closed-system made of a rigid short beam, perpendicular to the wall, to which two steel rebars were connected. These latter were hinged to both ends so that any parasite contribution of the test set-up to the overall response of the specimen was prevented. Similarly, spherical hinges were introduced in-between hydraulic jack and the overlying beam. In order to uniformly distributing the vertical load, two rigid I-beam were interposed between hydraulic-jacks and pier tops, on which levelled mortar layers were priorly realized. Horizontal cyclic displacement was applied to the wall top by means of a servohydraulic actuator, with a nominal capacity of $1250 \mathrm{kN}$ and $\pm 25 \mathrm{~cm}$ stroke, anchored to a vertical RC contrast. The actuator was equipped with a hinged head, with the aim to accommodate the actual deformed shape of the wall, fixed to a steel collar made of a couple of rigid plates located on the opposite sides of the wall and interconnected each-other by means of six steel bars, slightly pre-tensioned.

Main deformation sources were monitored during the test by means of a proper instrumentation system installed on both front and back sides of the wall specimen. Specifically, on the front side, a total of eight linear variable differential transformers (LVDTs) were installed at the location of critical end sections of the piers and central spandrel element, in order to measure axial displacements due to bending. On the backside, specific vertical LVDTs were mounted piers/foundation interface in order to measure the width of rocking-induced cracks. Those displacement transducers were complemented by two couples of vertical wire potentiometers (PTs) that measured the axial and bending deformations of each pier. Additional PTs were arranged along diagonals of piers and spandrel panel with the aim of monitoring shear deformations. Finally, a horizontal PT was installed at the same elevation of the actuator (i.e., $y=3055 \mathrm{~mm}$ ) and connected to a wall edge. 


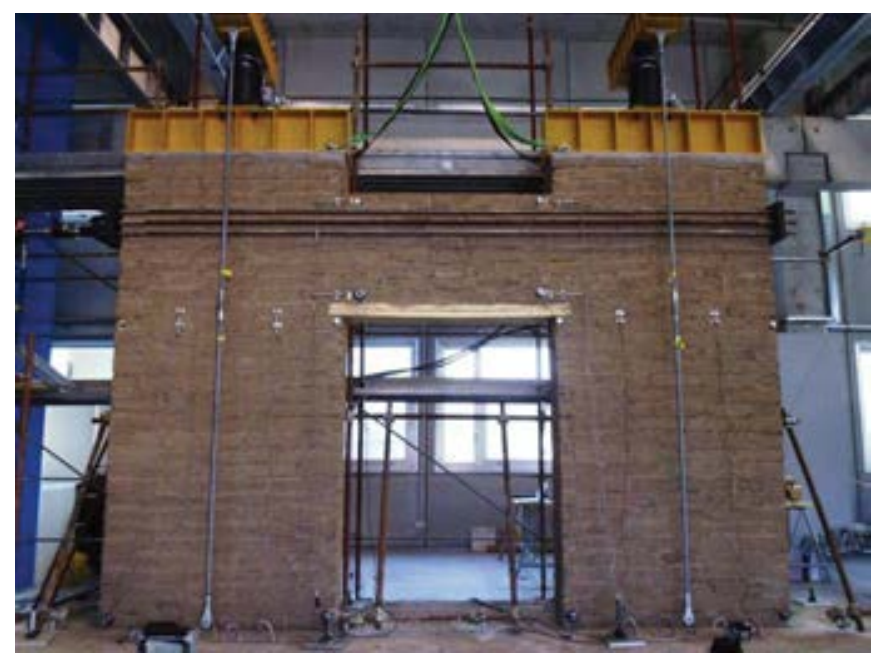

Figure 5: Test set-up and instrumentation installed on the adobe wall specimen before testing.

\section{$2.5 \quad$ Loading protocol}

Load application was performed in two consecutive stages. Firstly, vertical loads were applied on top of piers under force control in order to simulate gravity loads transferred by an ideal floor. After that effective contrast between jacks and piers were obtained, the axial load on piers was monotonically increased according to a force rate equal to $1 \mathrm{kN} / \mathrm{s}$ until load value of $88 \mathrm{kN}$ was reached (corresponding to $10 \%$ of the mean ultimate load of pier cross sections). Then, such value was kept constant during the second stage of the test when in-plane horizontal cyclic displacement was applied to the wall corresponding to the top of the spandrel, reproducing slab/wall transfer. The cyclic displacement history was composed of increasing displacement blocks of three cycles at a given amplitude peak until failure was observed. The amplitude was increased between consecutive blocks of $5.6 \mathrm{~mm}$. The displacement rate was set at $0.70 \mathrm{~mm} / \mathrm{s}$. The cyclic displacement history is shown in Figure 6 . A sampling rate equal to $5 \mathrm{~Hz}$ was of all instruments to ensure a proper monitoring of deformations during the entire test. The positive orientation was assumed as associated to a pushing action of the actuator. A total number of twelve displacement cycles were imposed on the specimen for a maximum displacement reached equal to $33.6 \mathrm{~mm}$.

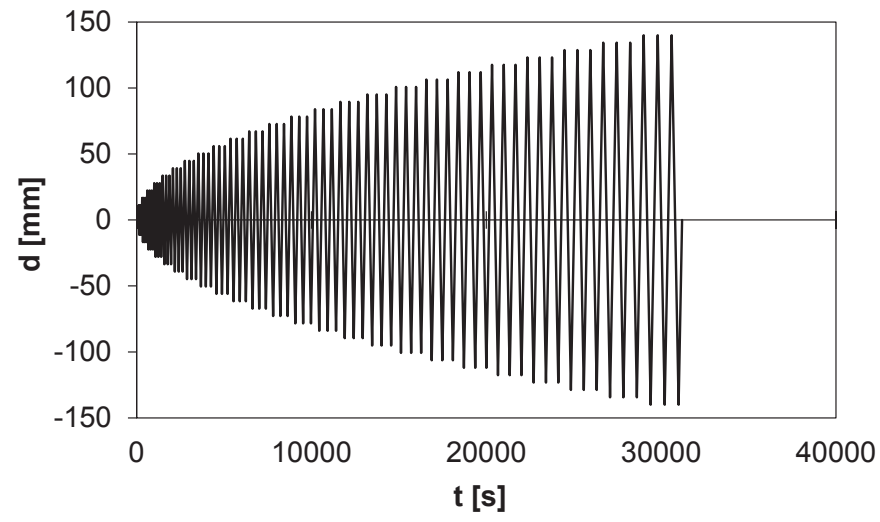

Figure 6: Cyclic displacement time history. 


\section{OBSERVED DAMAGE AND FAILURE MODE}

Figure 7 shows the damage occurred to the specimen at the end of the experimental test. Horizontal cracks were observed on both sides of the spandrel panel along different bed joints and extended to the whole length. On the lower part of the spandrel, in the proximity of the lintel, a partially inclined crack was observed towards the left-hand side end. Such a crack pattern is representative of shear failure mode. Overall, a quite moderate damage was observed on the spandrel. Conversely, both piers suffered large cracks on the bottom part. Specifically, sub-horizontal cracks concentrated in the first six/seven masonry layers from the base were firstly observed, subsequently evolving along inclined directions, mainly developed along mortar-joints. Corresponding to peak load condition, vertical cracks were observed within piers thickness due to failure of masonry in the compressed zone. Therefore, bending failure was experienced by the piers. Beyond the peak load, the wide cracks located at the base of the piers caused piers buckling and the experimental test was arrested when significant out-of-plane deformations were identified.

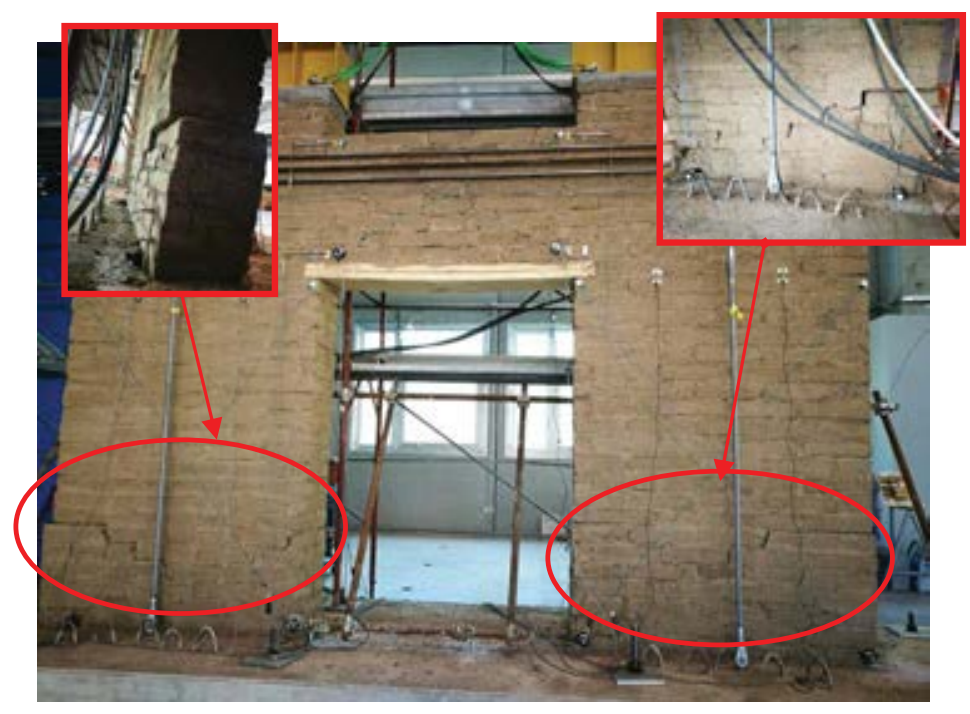

Figure 7: Damages observed on the specimen at the end of the experimental test.

\section{RESPONSE CURVES}

The horizontal load recorded by the actuator load-cell is plotted against the horizontal displacement measured by the PT positioned at the same height in Figure 8. Globally, the hysteresis curve appears quite symmetrical both in force and displacement for the first three cycles, whereas the fourth group of cycles was slightly asymmetrical due to onset of vertical cracks widening and piers buckling. The maximum horizontal force was reached in the positive orientation and was equal to $86.4 \mathrm{kN}$, whereas $81.4 \mathrm{kN}$ peak force was recorded in the opposite orientation. By assuming the lateral resisting force as the average of such values $\left(F_{\max }=83.9\right.$ $\mathrm{kN}$ ), a load-capacity value equal to approximately $31 \%$ of vertical load (apart from the effect of self-weight) was reached by the AM wall. Therefore, an in-plane acceleration-capacity of $0.31 \mathrm{~g}$ can be assumed for the specimens. The experimental test was stopped during the first cycle of the fifth loading block when a horizontal force of $61.4 \mathrm{kN}$ was attained on the last positive displacement cycle, evidencing approximately a $25 \%$ reduction in lateral resistance, for which evident out-of-plane deformations were observed. Regarding the deformation ca- 
pacity of the adobe wall, the maximum horizontal displacements reached in the positive and negative orientations of lateral loading were respectively equal to $31.81 \mathrm{~mm}$ and $34.50 \mathrm{~mm}$.

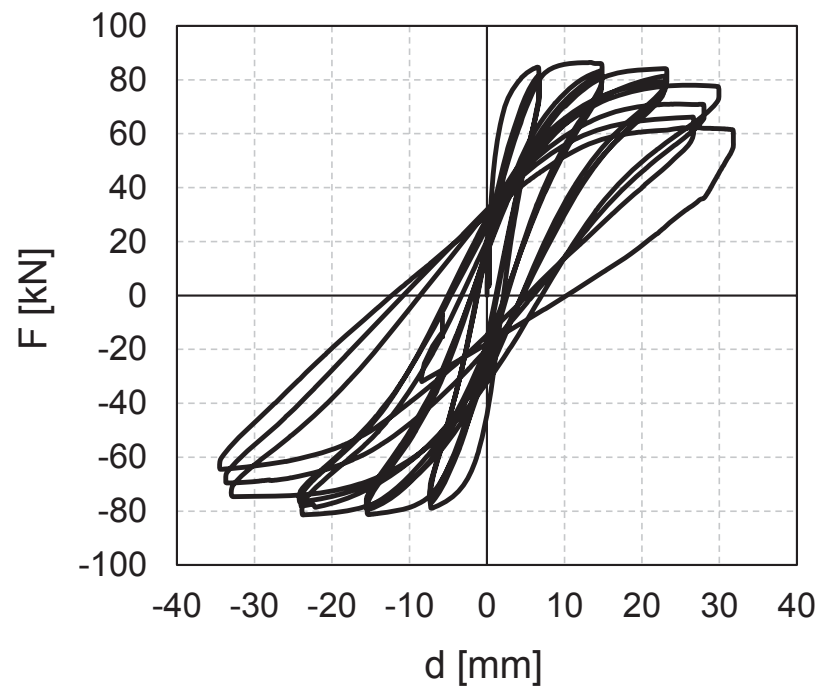

Figure 8: Force-displacement $(F-d)$ curve recorded during the experimental test.

The experimental response curve of the AM wall is reported in Figure 9 as backbone of the hysteresis cycles expressed in terms of lateral force versus inter-storey drift ratio $(F-I D R)$, the latter assumed as the measured lateral displacement normalized to the height of the horizontal loading line from the base of the piers. Within the framework of seismic performance-based assessment of masonry structures, establishing a relationship between limit states and observed damage appears crucial for response assessment as well as repair costs. Therefore, on the envelope curve, three performance levels (PLs) were identified representative of significant limit states of the wall:

- elastic limit (PL1), corresponding to diffuse cracks on wall members and herein associated to $0.6 F_{\max }$;

- peak condition (PL2), related to lateral peak-load attainment and for which severe damage was observed on the wall (such as, vertical cracks due to rupture of masonry under compression);

- ultimate limit state (PL3), identified when a drop in lateral force equal to $0.2 F_{\max }$ was recorded and representative of incipient loss of load-bearing capacity for the wall.

Mean values, between positive and negative directions, of force $(F)$ and inter-storey drift ratio $(I D R)$ corresponding to the above-defined PLs are summarized in Table 3. The AM specimen reached a $I D R$ value higher than $1.00 \%$ at failure, significant for a masonry structures, whereas peak condition was attained at about $I D R=0.61 \%$. Finally, the elastic behaviour was overcome at very early stage $(I D R=0.02 \%)$.

\begin{tabular}{llllll}
\hline PL1 & & PL2 & & PL2 & \\
\hline$I D R$ & $F$ & $I D R$ & $F$ & $I D R$ & $F$ \\
{$[\%]$} & {$[\mathrm{kN}]$} & {$[\%]$} & {$[\mathrm{kN}]$} & {$[\%]$} & {$[\mathrm{kN}]$} \\
\hline 0.023 & 50.3 & 0.606 & 83.9 & 1.043 & 67.1 \\
\hline
\end{tabular}

Table 3: Forces and inter-storey drift ratios associated with different performance limit states. 


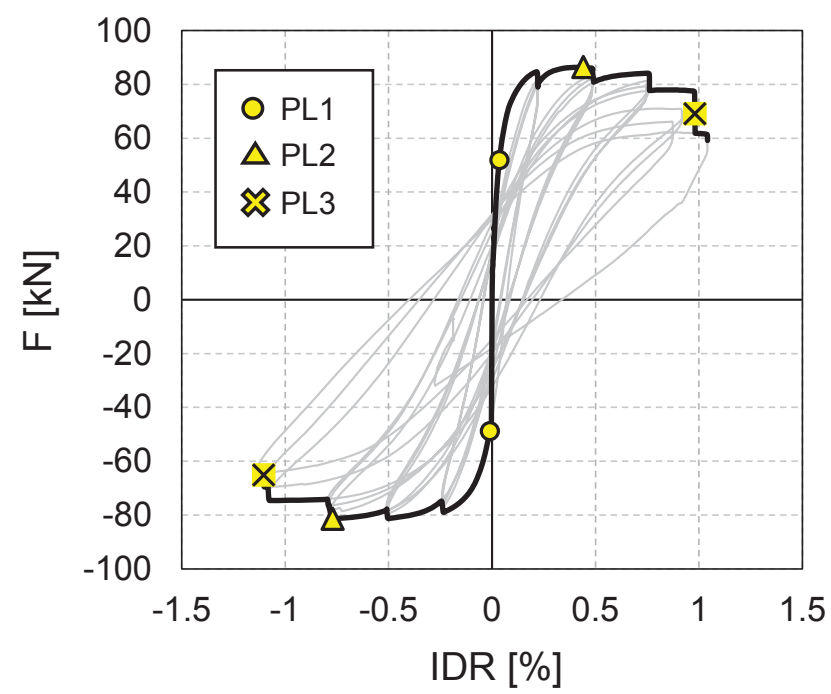

Figure 9: Experimental envelope in terms of force versus inter-storey drift ratio $(F-I D R)$.

\section{CONCLUSIONS}

In this study, the nonlinear response of a full-scale adobe masonry wall with a central doortype opening to cyclic lateral loading and constant vertical loading has been described. A detailed experimental characterization of masonry constituents, i.e. adobe bricks and mud mortar with peculiarities of existing Sardinian earthen dwellings, and of adobe masonry as a whole was carried out according to a multiscale approach. The geometry of the wall specimen, test set-up, measuring system and loading protocol have been described. Preliminary experimental results on the wall specimen have been discussed. Specifically, observed crack patterns and failure modes have been firstly described; then, damage states were related to the force-drift response by identifying specific performance levels. Based on such discussion, the following remarks can be pointed out:

- The wall specimen reached its lateral strength due to bending failure of masonry piers associated with extensive toe crushing at the base of piers.

- The spandrel panel suffered a relatively moderate damage, mainly due to shear action.

- The ultimate limit state of the wall was characterized by incipient loss of wall loadbearing capacity with visible out-of-plane deformations.

- The in-plane response of the wall was defined by premature cracking and relatively large ultimate inter-storey drift ratio, which was slightly larger than $1 \%$.

\section{REFERENCES}

[1] J.K. Bothara, R.P. Dhakal, J.B. Mander, Seismic performance of an unreinforced masonry building: an experimental investigation. Earthquake Engineering \& Structural Dynamics, 39(1), 45-68, 2010.

[2] F.L. Moon, T. Yi, R.T. Leon, L.F. Kahn, Testing of a full scale unreinforced masonry building following seismic strengthening. Journal of Structural Engineering, 133(9), 1215-1226, 2007. 
[3] E.L. Tolles, E.E. Kimbro, F.A. Webster, W.S. Ginell, Seismic stabilization of historic adobe structures: Final report of the Getty seismic adobe project. Los Angeles: Getty Publications, 2000.

[4] M. Blondet, J. Vargas, N. Tarque, Available low-cost technologies to improve the seismic performance of earthen houses in developing countries. In: Proceedings of 14th World Conference on Earthquake Engineering, Bejing, 2008.

[5] N. Augenti, F. Parisi, Learning from construction failures due to the 2009 L'Aquila, Italy, earthquake. Journal of Performance of Constructed Facilities, 24(6), 536-555, 2010.

[6] D.F. D'Ayala, S. Paganoni, Assessment and analysis of damage in L'Aquila historic city centre after 6th April 2009. Bulletin of Earthquake Engineering, 9(1), 81-104, 2011.

[7] L. Moon, D. Dizhur, I. Senaldi, H. Derakhshan, M. Griffith, G. Magenes, J. Ingham, The demise of the URM building stock in Christchurch during the 2010-2011 Canterbury earthquake sequence. Earthquake Spectra, 30(1), 253-276, 2014.

[8] D. Dizhur, R.P. Dhakal, J. Bothara, J.M. Ingham, Building typologies and failure modes observed in the 2015 Gorkha (Nepal) earthquake. Bulletin of New Zealand Society for Earthquake Engineering, 49(2), 211-232, 2016.

[9] L. Sorrentino, S. Cattari, F. Da Porto, G. Magenes, A. Penna, Seismic behaviour of ordinary masonry buildings during the 2016 central Italy earthquakes. Bulletin of Earthquake Engineering, 17(10), 5583-5607, 2019.

[10] D.P. Abrams, N. Shah, Cyclic load testing of unreinforced masonry walls. Advanced Construction Technology Centre Report No. 92-26-10. University of Illinois at UrbanaChampaign, IL, 1992.

[11] A.D. Mahmoud, A.A. Hamid, S.A. El Magd. Lateral response of unreinforced solid masonry shear walls: an experimental study. In: Proceedings of the 7th Canadian Masonry Symposium, Hamilton, 1995.

[12] K. Shahzada, A.N. Khan, A.S. Elnashai, M. Ashraf, M. Javed, A. Naseer, B. Alam, Experimental seismic performance evaluation of unreinforced brick masonry buildings. Earthquake Spectra, 28(3), 1269-1290, 2012.

[13] G. Magenes, G.M. Calvi, In-plane seismic response of brick masonry walls. Earthquake Engineering and Structural Dynamics, 26(11), 1091-1112, 1997.

[14] D. Benedetti, P. Carydis, P. Pezzoli, Shaking table tests on 24 masonry buildings. Earthquake Engineering and Structural Dynamics, 27(1), 67-90, 1998.

[15] T. Yi, F.L. Moon, R.T. Leon, L.F. Kahn, Lateral load tests on a two-story unreinforced masonry building. Journal of Structural Engineering, 132(5), 643-652, 2006.

[16] N. Gattesco, I. Clemente, L. Macorini, S. Noè, Experimental investigation of the behavior of spandrels in ancient masonry buildings. In: Proceedings of the 14th World Conference on Earthquake Engineering, Beijing, China.

[17] F. Graziotti, G. Magenes, A. Penna, Progetto di una sperimentazione su elementi di fascia muraria, Rapporto Reluis, Allegato 4.3-UR01-1. Università di Pavia and EUCENTRE, Pavia, Italy.

[18] K. Beyer, A. Dazio, Quasi-static cyclic tests on masonry spandrels. Earthquake Spectra, 28(3), 907-929, 2012. 
[19] A. Chourasia, S.K. Bhattacharyya, N. M. Bhandari, P. Bhargava, Seismic performance of different masonry buildings: full-scale experimental study. Journal of Performance of Constructed Facilities, 30(5), 04016006, 2016.

[20] N. Augenti, F. Parisi, A. Prota, G. Manfredi, In-plane lateral response of a full-scale masonry subassemblage with and without an inorganic matrix-grid strengthening system. Journal of Composites for Construction, 15(4), 578-590, 2011.

[21] C.L. Knox, D. Dizhur, J.M. Ingham, Experimental cyclic testing of URM pier-spandrel substructures. Journal of Structural Engineering, 143(2), 04016177, 2017.

[22] C.L. Knox, D. Dizhur, J.M. Ingham, Two-story perforated URM wall subjected to cyclic in-plane loading. Journal of Structural Engineering, 144(5), 04018037, 2018.

[23] T. Choudhury, G. Milani, H.B. Kaushik, Experimental and numerical analyses of unreinforced masonry wall components and building. Construction and Building Materials, 257, 119599, 2020.

[24] M.K. Howlader, M.J. Masia, M.C. Griffith, In-plane response of perforated unreinforced masonry walls under cyclic loading: Experimental study. Journal of Structural Engineering, 146(6), 04020106, 2020.

[25] C. Atzeni, Stone masonry in rural Sardinian building. Evolution of the traditional building techniques between XIX and XX Century. In: Proceedings of the First International Congress on Construction History, Madrid, 2003.

[26] F. Parisi, D. Asprone, L. Fenu, A. Prota, Experimental characterization of Italian composite adobe bricks reinforced with straw fibers. Composite Structures. 122, 300-307, 2015.

[27] A. Caporale, F. Parisi, D. Asprone, R. Luciano, A. Prota, Micromechanical analysis of adobe masonry as two-component composite: Influence of bond and loading schemes. Composite Structures; 112, 254-263, 2014.

[28] F. Wu, G. Li, H.N. Li, Q. Jia, Strength and stress-strain characteristics of traditional adobe block and masonry. Materials and Structures, 46(9), 1449-1457, 2013.

[29] EN 1926. Natural stone test methods - determination of compressive strength. Brussels: Comité Européen de Normalisation; 1999.

[30] EN 1015-11. Methods of test for mortar for masonry - Part 11: Determination of flexural and compressive strength of hardened mortar. Brussels: Comité Européen de Normalisation; 1999.

[31] ASTM. ASTM E 519-15. Standard test method for diagonal tension (shear) in masonry assemblages. ASTM International, West Conshohocken, PA, USA; 2015. 